

98. zenb.

XXXIX. URTEA

2021 UZTAILA-ABENDUA

ISSN 2530-3287

Ximena

Miranda Olea

anemix77@gmail.com @anemix77ximena

Bestelako lankidetzak

\title{
Helduen irakaskuntza eta lineako taldeen dinamika
}

Ikasgelan izaten den sozializazio-giroa: horixe izan daiteke, hain zuzen, pertsona bat helduaroan bigarren hizkuntza ikasteko erakarrita sentitzeko arrazoietariko bat. Horregatik, eskolak urrutiko bihurtzen direnean, parte-hartzaileen arteko elkarreraginerako espazio sozial horri eustea du erronka irakasleak. Horretarako, ezinbestekoa da irakasleen jardunbide egokietara jotzea giro egokia sortzeko, non elkarreragina sustatuko baita. Ikaskuntzaingurune berri horietan talde osasuntsu eta eraginkorrak eratuz, giro sozial horri eutsi ahalko zaio klase hibridoetan. Hasteko, ikasle-mota horren eta azken aldian gertatu diren aldaketen alde orokor batzuk gogoratu behar dira. Ondoren, proposamen didaktiko batzuk zehaztuko dira.

\section{Gako-hitzak}

asinkronoa, booktuber-ra, buletina, irakurketa-kanpainak, klase hibridoak, knolling-a, sinkronoa, talde-dinamikak

\section{HELDUEKIN ETA KLASE HIBRIDOEKIN LAN EGITEKO OINARRIAK}

\subsection{ABIAPUNTUA}

Pertsona heldu batek prestakuntza-ikastaroetan izan behar duen inplikazioak eta konpromisoak helduaroko bizitzari dagozkion askotariko interesen eta kezken baitan egon behar du (lana, familia, ikasketak, osasuna...). Horregatik, pertsona helduei zuzendutako H2ko gelako jardueren proposamenak ahalik eta erakargarriena izan beharko luke, gure ikasleen interesa ahuldu ez dadin, gure ikasturtean parte hartzea erabaki baitute.

Bestalde, egoera berri honetan, ikasleak argi izan behar du hasiko duen ibilbidearen nondik norakoa; etapen eta baliabideen oharrak gogoraraziko dira, galduta senti ez dadin eta alde egin ez dezan. Hau da, irakaskuntza-baliabidetzat jo behar da zenbait kontu argi azaltzea - hala nola ikastaroaren helburuak, jarduerak egiteko erabili beharko dituen tresnak, komunikazio-kanalak edota ebaluazioa egiteko modua-, ikasleak ez dezan ikastaroa bertan behera utzi eta ikaskuntza-espazio berri horretan seguru senti dadin. 
Era berean, komunikazio-egoera erakargarriak hautatzeko, ikaslea bere prestakuntzaren parte aktibo senti dadin, estrategia baliagarriak dira haien gustuei eta lehentasunei buruzko galdetegien bidez informazioa jasotzea, aurkezpen-jarduerak eta/edo aurretiazko elkarrizketak. Horrela, interesari eutsiko dio eta jarduerak egiteko inplikatuko da, eta gutxienez ikaslearen parte hartze etengabea lortuko da, baita hura areagotzea ere.

Beste laguntza-euskarri bat da lan-ingurune berri horietan antolatzea, beste edozeinek bezala, arau eta erregela batzuk behar dituen heinean. Egoera berri honetan ezin dira oinarrizko arauak alde batera utzi. Horregatik, erabilgarria da arau bat negoziazioaren bidez erabakitzea (adibidez, entrega-datak edo eztabaidagaiak); izan ere, ikaslea erabaki horietan partaide eginez, haren konpromisoa indartzen da zeharka. Gainera, konpromiso bat betetzeko behar den erantzukizuna lotuta dago norberaren ikaskuntzaprozesuarekiko zein taldearekiko errespetuarekin. Hau da, itundutakoa betetzen ez bada, taldeko kide izatearen sentimendua murriztu egiten da, eta, aitzitik, adostutako erabakiak errespetatuz gero, taldearen kohesioa indartu egiten da. Jakina, salbuespenak onartzeko malgutasuna beti egongo da irakasleen eta ikasleen arteko harremanetan sortu den konfiantzaren mende.

Azkenik, ikasgelako espazioa ingurune berri horretan eraldatzea txandakatu egin da ikasgelako espazio fisikoaren eta digitalaren artean. Oro har, urruneko klaseak eta soluzio misto edo hibrido bat eman dira, eta hurrengo atalean xehetasun batzuk ikusiko ditugu.

Gogoeta horiek kontuan hartuta, has gaitezke ezaugarri batzuk zerrendatzen irakatsi eta ikasteko testuinguru berri honetan, zeinek lagundu diezaguketen jardun-ibilbide bat hobeto "marrazten".

\subsection{ALDAKETAREN ERAGILEAK}

Lau osagai ditu gure irakaskuntza-jardunaren egiturak: ikasleak, irakasleak, erakundea eta gela. Bakoitzak bere eginkizunaren barruan hartzen du arreta, prestakuntza-egoeraren aldaketa horretan egokitzeko.

1. Ikasleak. Eragile nagusiak dira, eta haien parte-hartze aktiboa are funtsezkoagoa da ikaskuntza-ingurune berrietan; horretarako, estimulu egokiak jaso behar dituzte, ikaskuntza eraginkorra izan dadin; gainera, beren prestakuntzan autonomia garatzera bideratuta egon behar dute, lankidetza-jarduerak proposatuta.

2. Irakasleak. Ikaskuntza-prozesuan ikasleak gidatzeaz gain, beharrezko materiala eta baliabideak emanez, horretarako egokiak diren gaitasun digitalak eskuratu beharko dituzte.

3. Erakundeak. Prestakuntza-proiektuaren alde administratiboa.

4. Ikasgela. Ingurune berrietan, klase hibridoen berezko dualtasuna hartu beharko dugu kontuan, hau da, ikasgelako espazio fisikoaren eta laguntza-ingurune digitalaren konbinazioa. Gure ustez, Laguntzeko Ingurune Digitalak (LMSLearning Managment System) ikastaroa ematen den ikastetxeko ofiziala izan beharko luke; beraz, erakundeak dagoeneko plataforma bat eskaintzen badu, hori erabili beharko litzateke. Baina, hala ez bada edo baliabide osagarri bat erabili nahi bada, ekosistema digitalak eskaintzen dituen ikaskuntza-plataformen aukeretara jo daiteke (Moodle, Blackboard, Google Classroom, besteak beste). Hala, ikasgela askotariko dimentsioko espazio likidotzat hartzen da, non teknologia eta pedagogia uztartzen diren; likidoa da espazioaren eta ekintza pedagogikoaren arteko harremana hedatu egiten delako eta ohiko gela presentzialean jarduerak ematen duen eskola-denboratik haratago doalako.

\subsection{IKASKUNTZA ERAGINKORRERAKO ESTRATEGIAK}

Ikaskuntza eraginkorra lortzeko oinarrizko estrategia batzuk honako hauek dira: lanagertokia funtsezko bi kontzeptutatik abiatuta aztertzea: denboratik eta espaziotik. Alde batetik, espazioa, ikasgela hibridoaren (ikasgela fisikoa) eta ingurune digitalaren 
(lineako ikaskuntza-ekosistema edo -plataforma edo ekosistema) artean zatitutakoa dena. Bestalde, ikaskuntza-jarduerak bi denboratan garatzen dira: asinkronoa (ez zuzenean) eta sinkronoa (zuzenean).

Bigarren estrategia baliabide teknikoen kontrolari buruzkoa da: kamerak, mikrofonoak, proiektoreak, monitoreak, ordenagailuak... eta altzariak (arbelak, mahaiak, aulkiak ...).

Hirugarrena plangintza-lana da, hau da, jardueren aukeraketa eta horien sekuentziazioa, materiala eta ematen den informazioa espazioaren (ikasgela hibridoa - plataforma digitala) eta denboraren (sinkronoa - asinkronoa) artean banatzen dira. Klaseen diseinua eta programazioa errazteko, honako jarraibide hauek baliagarriak izan daitezke:

- Zer? Hasieratik argi izatea ikasleari eskaintzen zaion materiala eta material horren funtzioa. Adibidez: zer jarduera proposatuko die nire ikasleei? zein da ekimen honen helburua?

- Noiz? Lanak emateko egutegia egitean, ikasleak jarraipen zuzena izango du. Horrela, ikaslearen konpromisoa eta autonomia sustatzen ditu. Adibidez: noiz eman beharko dute?

- Non eta nola? Gure ikastaroetan aktibatuko diren tresnak argi eta garbi azaldu behar dira; horregatik, azalpen eta jarraibide argiak eman behar dira eskatzen zaizkien lanak non, noiz, nola (kanala eta formatua) eman behar dituzten jakiteko.

Azkenik, eskola-saio bakoitzaren (asinkronoa eta sinkronoa) helburuak argi eta garbi identifikatzeko, irakasleek une bakoitzean bete behar dituzten funtzioak hartu behar dira kontuan. Horregatik, garrantzitsua da klase hibridoak 3 etapa dituela ikustea: lehenago, bitartean eta ondoren. Eskema honek etapa bakoitzeko zenbait funtzio jasotzen ditu.

1. irudia. Nebrija Unibertsitatea, 2020 (egokitua)

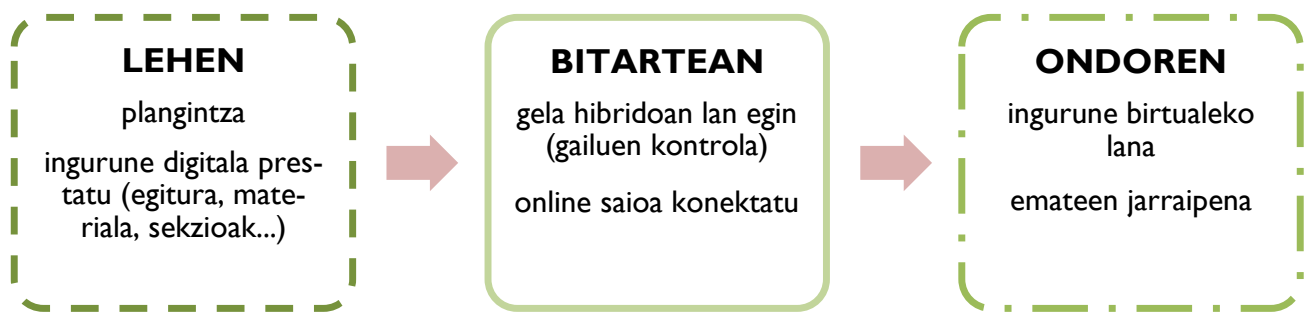

Dena den, aldaketaren une bakoitzean norantz goazen hausnartu behar dugunez, errepara diezaiogun Herrerak eta Pujolàk egindako galderari $(2020$, 4). Horrenbestez, kontua da jarduera asinkrono-sinkrono mota bat bereiztea benetan garrantzitsua den edo proposatzen diren jardueren helburu nagusia garrantzitsuagoa den. Agian, merezi du beti atzera egitea eta jarduera jakin baten helburua zein den eta hizkuntza-eduki jakin bat ikasteko benetan garrantzitsua ote den galdetzea.

\subsection{PERTSONEN ARTEKO HARREMAN ONAK, ONLINE IKASGELAN}

Ingurune berri horietan, ez dira alde batera utzi behar lankidetza-lana sustatzen duten jarduerak, esperientzia esanguratsuak sortze aldera. Gogoan izan taldekide bakoitzaren inplikazioa ikasgelan elkarri eragiteko dauden aukeren araberakoa izango dela. Horretarako, klase hibridoetako taldeetan lan-dinamikak aplikatzen jarrai daiteke, zailtasun handirik gabe.

2020ko itxialdietan sortu zen arazoetako bat izan zen parte-hartzaileren batek prestakuntza-jarduera uztea. Horregatik, lan-testuinguru hibrido baten aurrean, bistakoa da 
talde osasuntsuak eratzeak garrantzia handia duela; izan ere, talde bateko kide sentitzeak talde horretako kideekiko interesa, konpromisoa eta erantzukizuna eskatzen du. Horregatik, irakaslearen asmoetako bat ikasgelan giro ona lortzea izan beharko litzateke, ikasgelako kideen artean elkarreragin osasuntsu eta naturala errazteko. Ikasgela sozializatzeko lekutzat jotzeak berez ekarri beharko luke kide bakoitzaren inplikazioarekin eta parte-hartzearekin lotutako alde pertsonalei buruz galdetzea eta alde haiekiko interesa erakustea; izan ere, norbait zailtasunen bat bizitzen ari bada, bere zailtasunak partekatzea lagungarria da, eta, beste aldetik ere, baliagarria dela sentitu ahal izango da, eta ahal den neurrian lagundu. Horregatik, pertsonen arteko harreman osasuntsuak egotea lortzen badugu, hau da, gure ikasleen arteko lotura onak, ikasgelan giro ona izatea, errazagoa izango da ikastaroa zergatik utzi duten disimulurik gabe galdetzea, eta, horrela, berriz itzultzen lagundu ahalko da. Beti izaten da ona norbait zure zailtasunekiko interesatuta dagoela jakitea, eta beste aldetik ere, lagundu ahal izatea.

Era berean, elkarlaneko lanak funtziona dezan eta ikaskuntza eraginkorra eragin dezan, komeni da ikertzea eta antzematea nola sentitzen den ikaslea ikasgelan zereginak egitean; egoera gatazkatsuak saihestea ere komeni da. Lineako eskoletan eta beste edozeinetan faktore afektiboa zaintzea funtsezko osagaia da; izan ere, proposatzen diren jardueren funtzionamendu egokia sortzen diren harremanen araberakoa da, eta, nola ez, taldean gainditzen diren gatazken araberakoa. Lan egiteko ingurunea zaintzea ikasleen portaerari arreta jartzea da. Horregatik, euskarri digitalekin eta komunikazio- eta interakzio-kanal desberdinen bidez lan egiteak eskatzen duen ahalegina gorabehera, behaketa ez da ahaztu behar, hau da, konturatu behar da ikasleek nola jokatzen duten, nola erlazionatzen diren, nola jokatzen duten, zer emozio antzematen diren. Hemen erabilgarria da gure ikasleen ezaugarri orokorrak berriz kontuan hartzea, lehen ikusi ditugunak, baita ikaskuntza-ingurune berri batean (urrutitik, hibridotan, aurrez aurre eta zenbait murriztapenekin) egoteak ekar ditzaken tentsioa eta nerbioak ere. Horregatik, irakaskuntza-estrategiak egokitu besterik ez da egin behar.

Dörnyei-k eta Murphey-k (2006) deskribatzen dituzten taldeen eraketan 4 faseak daude, eta oso lagungarriak dira horiek gure egungo testuinguruan gogoratzeko, batez ere klase hibridoko jardueren tipologia hautatzeko. Hona aipatutako faseak:

1. taldearen eraketa

2. trantsizioa

3. performantzia

4. desegitea

Fase horietako bakoitzaren ezaugarriak kontuan hartuta, une bakoitzerako jarduera egokiagoak proposatzen dira. Adibidez, taldekideak onartzea sustatzen den lehen jardueretan, elkarrengandik ikas dezaten, haien gustuei, lehentasunei eta interes pertsonalei buruzko informazio-trukea sustatzen duten jardueren bidez, jarrera tolerantea garatzeko. Era berean, espazio digitalean ikasleen arteko lankidetza ahalbidetzea, kideak talde gisa identifikatzeko jarduerak sortuz, hala nola erronka txikiak, non lehiaketa on batek talde-kohesioari mesede egiten dion.

Bigarren fasean, berriz, ez da nahitaez aurkeztu behar, eta, bertan, taldean gatazkak antzeman daitezke eta konpondu egin beharko lirateke. Kasu horretan, irakaslearen bitartekaritza funtsezkoa da sortzen diren oztopoak gainditzeko. Irakaslearen zereginetako bat gatazkak aurreikustea da (adibidez, talde-lanean inplikaziorik eta parte-hartzerik eza), bai eta neurri eta estrategia erabakigarriak prestatzea ere, hau da, jarduteko erantzun ordenatua izatea gatazka horiek erabiltzeko.

Gatazka-egoera bat ebaluazio-irizpide bat ez ezagutzetik sor daiteke; adibidez, lan bat garaiz ez ematetik. Hori gerta ez dadin, argi eta garbi azaldu behar da emateko puntualtasuna ebaluazio-irizpide bat dela lana esleitzen den unean, eta ez geroago. Beraz, ebaluazio-irizpideak hasieratik ondo zehaztuta eta azalduta egotea gomendatzen 
da. Ikasleak horretaz jabetzen direla egiaztatzeko, jakin beharko lukete 3 galdera hauei erantzuten:

- zertan datza talde-lana?

- nola egiten da zeregin, jarduera edo proiektu bat?

- noiz eman behar da?

Hirugarren fasean, lana banatzeko unea da; taldeak gai izan beharko luke lanaren funtzioak mikrozereginetan banatzeko. Adibidez, informazioa zenbait iturritan bilatzea, lanaren formatua eta/edo konposizio grafikoa aukeratzea, informazioa hautatzea eta azken lana aurkeztea. Mikrozeregin bakoitzak dakarren lan-kargaren arabera, arduradun bati edo batzuei egokitu behar zaie; horrela, lana modu orekatuan banatzen da eta kide bakoitzak funtzio bat du talde-lana egiteko.

Amaitzeko, gogorarazten da talde bakoitzak, hasiera batean, iraungitze-data duela; hau da, ikastaroak, proiektuak edo jarduerak irauten duen denboraren arabera sortzen da. Edozein agregaziotan bezala, lantaldeak eboluzio-prozesu bat du, eta, horrenbestez, ezinbestekoa da ikasleei baterako lana amaitzeko unera bideratzea. Beste modu batera esanda, une hori hasieraren eta prestakuntza-unearen antzera zaindu behar da. Itxierako une honetarako jarduera egokiak autogogoetako atazak dira, ikasleari bizitako lanesperientziaz jabetzeko aukera ematen diotelako. Fase horretan, zenbait jarduera egitea gomendatzen da, hala nola ebaluazio-galdetegiak, irteera-txartelak eta/edo berripaperak (newsletter-rak).

Galdetegiak ez lirateke luzeak izan behar, beldurgarriak ez izateko eta erantzunetan automatismoa saihesteko. Dokumentu-mota horretan, ikasleari galderak egin beharko litzaizkioke, ikaskuntza-prozesuan izan duen parte-hartzean eta inplikazioan eragina izan zezaketen alderdiak ardatz hartuta. Adibidez, proposatutako jarduerekin eroso sentitu den eta ikasgelatik kanpo baliagarri izango zaizkizula edo erabilgarriak izango zaizkizula uste duzun. Ikasgelatik kanpoko lan-karga gehigarria esanguratsua izan den ala ez, eta, horretaz gain, ikastaroaren alde teknikoarekin lotutako irizpideak ere bai, hau da, eskoletan proposatutako baliabideak erabiltzea erraza izan den. Azkenik, irakaslearekiko eta ikaskideekiko tratua eta harremana. Hau da, ikastaroaren osagai ezlinguistikoei buruzko hausnarketa helburu duten galderak.

Irteera-txartelak (Ruiz, López eta Torres, 2021), ordea, galde-sorta ahalik eta gehien gutxitzeko modutzat har daitezke. Hau da, lan egiteko moduari eta sentitzeko moduari buruzko 3 edo 4 galdera dira. Txartelak klasearen amaieran edo jarduera-sekuentzia bat amaitzean proposatzen dira, eta denbora gutxi eman beharko lukete. Horrela, informazio garrantzitsua biltzen da ikasleek jardueren helburuak eta horien garapena une zehatz eta azkar batean ulertu dituzten jakiteko. Jarduera mota horrek zenbait zailtasun zehatz detektatzeko balio dezake, baita gaindiezinak bihurtu aurretik balioztatzeko ere.

Ikasleei zer ikasi duten hausnartzeko eta zer edo nola bizitzen ari diren adierazteko aukera ematen dieten tresnak dira galdetegiak eta irteera-txartelak. Horregatik, jarduera horiek ahalik eta kontu handienaz proiektatu behar dira, eraginkorrak izan daitezen. Halaber, atzeraelikadura baliagarria izan behar zaio irakasleari puntu ahulak indartzeko, akatsak konpontzeko, zailtasunak gainditzera animatzeko eta ikaslearen lorpenak aitortzeko.

Azkenik, Dörnyeik eta Murpheyk (2006) proposatzen dituzten buletinek taldean aktiba daitekeen posta-trukeari egiten diote erreferentzia. Kasu honetan, helburu didaktiko argi batekin, irakasleak taldeak osatu beharko lituzke, eta korrespondentzia-mota horretan partekatuko diren gaiei buruzko jarraibideak eman beharko lituzke. Adibidez, kultura-intereseko informazio orokorrak, ikasleek jardueren garapenari buruz dituzten iritziei buruzko galderak, ikasgelan ikusitako eduki zehatzen bati buruzko zalantzak eta kontsultak. Korrespondentzia-truke mota hori modu itxian eta pribatuan (irakaslearen 
eta ikaslearen artean) edo modu ireki eta publikoan (irakaslearen eta ikasgela osoaren artean) proposa daiteke.

Lan-eremua zaintzea da helduentzako prestakuntza-gelako parte-hartzea eta motibazioa ez galtzeko bigarren jarraibidea. On line ingurunerako portaera- eta zaintza-arauak ezartzea erabilgarria izan daiteke, gelako sarrera mentalki prestatzen duten ekintza txikiak baitira. Adibidez, hasteko, ikasleei eska dakieke kamera piztu ezin bada, argazki bat jar dezatela pantailaren atzean nor dagoen eta norekin jardungo dugun jakiteko, garrantzitsua baita geure burua identifikatzea esperientziak eta iritziak trukatu ahal izateko.

Beste adibide bat itxaronaldiak giro-musikarekin gozatzeko musika jartzea da, baita jardueren denbora kronometratzeko eta erregulatzeko ere. Musika aukeratzerakoan, une haietarako musika-zerrenda bat sortzen parte hartzeko eska dakieke. Horrela, lehen aipatu den talde-kohesioaren alde egiten da.

Azkenik, talde-lanari zuzenean dagokio lankidetzako espazio digitaletan, non informazioaren hautaketa eta negoziazioa ikaslearen praktika aktiboaren parte diren. Ikasgelan dauden parte-hartzaileen eta urrutitik parte hartzen dutenen arteko trukea errazteko, komunikazio-kanalak behar bezala aktibatuta daudela ziurtatu beharko litzateke; horregatik, zenbait konponbide posible izatea komeni da beti. Bat-bateko mezularitza edo ikastaroko plataforma digitalean eztabaida-foroak sortzea izan daiteke horietako bat. Horrela, ikasgelako zuzeneko konexioaz gain, ikasleen arteko elkarreraginean laguntzen duten aldi bereko elkarrizketak izaten dira. Adibide gisa, "nire online eskolarako arauak" infografia baliagarria izan daiteke (2. irudia).

\section{2. irudia. Nire online eskolarako arauak (Iturria: berezko ekoizpena).}

Nire online eskolarako arauak

\#I Jarri argazki bat zure profilean

- Denoi gustatzen zaigu jakitea norekin ari garen lanean.

\#2 Galdetu ezazu nola dauden, nola sentitzen diren

- Pasatu zerrenda, eta galdetu nola dauden zure ikasleak, non dauden eta nola sentitzen diren.

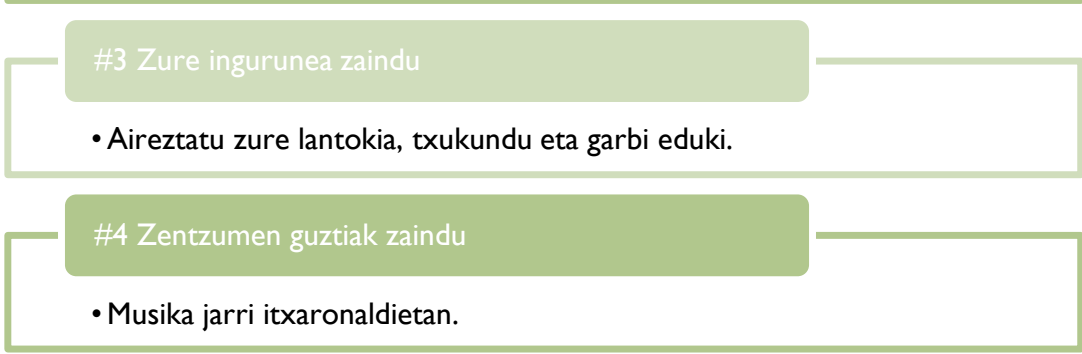

\#5 Lankidetza-lanerako espazioak sortu

- Lantaldeak, aretoak (breakout)

- Padlet, drive eta antzeko aplikazioak 


\section{LEHEN EGINDAKO JARDUEREN IDEIA OROKORRAK ORAIN HIBRIDOAN GARATZEKO}

Zalantzarik gabe, urrutiko didaktika agertzeak nahasmen, desorientazio eta presio orokorraren sentsazioa eragin du, irakasleen zein ikasleen kolektiboarengan. Irakasleentzako ikaskuntza-ekosistemen, aplikazioen, joera pedagogiko berrien eta etengabeko prestakuntzaren eskaintza amaigabeak agian ez du asko lagundu tresna onena zein den aukeratzen. Aukeraketan, erabilgarria izango litzateke egoera berri honetan irakaskuntza-lana norantz bideratzen den aztertzea eta horri buruz hausnartzea (Herrera eta $\mathrm{Pu}$ jolà, 2020, 2).

3. irudia. Iturria: berezko ekoizpena, Herrera eta Pujolà (2020) oinarri hartuta



Hori horrela, berrikuntza didaktikorako izenburuen azalpenari jarraituz, ingurune berri honetarako moldatutako proposamen didaktiko batzuk berreskura ditzakegu:

1. Masterclass. Gonbidatuak gai batean. Ikasleek galderak prestatzen dituzte eta gero eztabaida egin daiteke. Gonbidatua urrutitik egon daiteke.

2. Eztabaidak. Ikasleen intereseko gaiak biltzea, azter daitezen, eta, ondoren, bateratze-lana egin dezaten.

3. Egunkariak, paper-zorroak edo koadernoak egitea. Horrelako jarduerak oso erabilgarriak dira prestakuntza-ebaluaziorako.

4. Arazoak konpontzeko jarduerak. Mota guztietako enigmek talde-kohesioa errazten dute, baita ikasleen arteko elkarrergina ere, hezkuntza-testuinguru desberdinetan.

5. Rol-jokoa (de Ágreda, 2021). Rolen banaketa ez litzateke arazo bat izan behar testuinguru hibrido batean, kontrakoa baizik.

6. Proiektuetan Oinarritutako Ikaskuntza (Trujillo, 2017). Ikaslearen benetako ingurunetik ahalik eta hurbilen dauden egoerak lantzea, helburu komun batzuekin taldean egiten jakitea sustatzeko. 
7. Ikaskuntza-giroak sortzea. Ikaskuntza-testuingurua helburu espezifikoak dituzten zenbait espaziotan antolatzea, jarduera librea eta ikerketa sustatuz. Horretarako, garrantzitsuak dira ikasleari eskaintzen zaizkion materialak. Ikaskuntza-espazioak ikasleek libreki aukeratzeko proposatzen dira.

8. Gamifikazioa (Herrera, 2017). Jolas-estrategiak ikasgelan aplikatzea da helburua, hezkuntza-helburuak lortzeko.

9. Ikasgela iraulia (Herrera eta Pujolà, 2020). Metodologia honetan, ikus-entzunezko materialak elkarlanaren bidez eskaintzen dira, oro har. Ikaslearen autonomia sustatzen du, IKTek eskaintzen duten maneiuan oinarrituta.

\section{PROIEKTUEN PROPOSAMENA}

Jarraian aurkezten diren proiektuak testuinguru hibrido batean ikaskuntza eraginkorra lortzeko estrategietan kokatzen dira (ikus 1.3. Ikaskuntza eraginkorrerako estrategiak). Oro har, ezaugarri espezifiko batzuen arabera, sinkronoak eta asinkronoak bereizten dira; hemen, ordea, jarduera sinkronoen eta asinkronoen arteko plangintza, kasu batzuetan, landu nahi den uneko helburu didaktikoaren arabera truka daitezke. Jarduerak, berez, taldearen beharretara moldagarriak dira, lantzeko behar den denbora kontuan hartuta.

Baina, oro har, jarduera sinkronoetan, irakasleak zuzenean ikusi beharko lituzke ikasleen ekoizpenak eta elkarreraginak. Horrela, esku har lezake, aholkuak emanez, ikaslea gidatzeko eta laguntzeko, baita hari aholkuak emateko ere. Era horretakoak izan daitezke, halaber, antzemandako arazoak konpontzen dituztenak, hala nola akats arruntak edo argi geratu ez diren puntuak, irakaslearen iruzkinen eta ikaslearen parte-hartzearen bidez.

Jarduera asinkronoak, berriz, denbora gehien behar izan dezaketenak dira, ikasleak bere ikaskuntza-estrategietara jo ahal izan dezan eta bere autonomia garatu ahal izan dezan. Horrelako jardueretan, jarraibideak argiak izan behar dira, hala nola, emate-datak eta -modua, egiteko erabili behar diren baliabideak eta tresnak; gainera, aldeko jarrera piztu behar dute, non ikaslearen konpromisoa eta erantzukizuna funtsezkoak diren ezarritako helburuak lortzeko. Adibidez, foro batean parte hartzea eta tankerako jarduerak baliagarriak izan daitezke irakasleak eskakizunak errespetatzen joateko, ohar linguistikoez gain.

Horretaz guztiaz gain, jarraian aurkezten diren proiektuek ekosistema digitaleko zenbait erreferentziatatik hartutako ideien multzoa irudikatzen dute. Zenbait jarduera elkartu nahi izan dira, hizkuntza-edukiak ez ezik, hori baino zerbait gehiago ere izan dezakeen irakaskuntza-praktika batean gauzatzeko, espazio digitala ahalik eta hurbilen eta afektiboena eginez, sozializazio-osagaiari eusteko (bigarren hizkuntzako ikasgelaren oso ezaugarria dena). Zehatzago esanda, hemen klase hibridoetarako bi proiektuproposamen eskaintzen dira. Ikasleei proposatzen zaien lanean zenbait konpetentzia garatu nahi dira: irakurketaren eta ikus-entzunezkoen ulermena, digitala, pertsonala, soziala eta ikastekoa.

Bi proiektuen jarduera-sekuentzia gorago azaldu diren bi parametroen barruan kokatzen da: taldearen eraketaren lau faseak eta hezkuntza-agertoki hibridoa (denbora sinkronoa edo asinkronoa).

\subsection{BIDEO BAT BOOKTUBER GISA GRABATZEA}

Irakurketa bat hautatu behar da, "booktuber" erako bideo bat egiteko. Helburu nagusia H2an irakurketa sustatzea da, hau da, ikasleen irakurtzeko interesa piztea, norberaren gozamena aurkitzeko. Jardueren sekuentziaren helburu orokorrekin batera, praktikan jarri nahi direnak gehitzen dira, eta, horretarako, booktuber-ren ezaugarriei buruzko literatura-edukia duen bideo bat egiten da. Horregatik, ebaluazioan hizkuntza-gaitasunen 
garapena soilik hartu beharko litzateke kontuan, baita gaitasun digitalaren trebetasunak eta jarrerak garatzen diren gaitasunak ere.

Hona deialdi honekin lortu nahi diren helburu nagusiak:

- Ikasleak H2ko liburuen egungo izenburu batzuekin harremanetan jartzea.

- Booktuber bateko bideo baten edukia eta ezaugarriak ezagutzea.

- Testu baten informazio nagusiak eta booktuber-bideoak bereiztea.

- Testu bati buruz duten balorazioa eta iritzia azaltzen jakitea.

- Informazio espezifikoa aurkitzea, argudioak indartzeko.

- Informazioa hautatzeko estrategiak praktikan jartzea.

- Laburpen bat idazten jakitea.

- Benetako materiala erabiliz lexikoa zabaltzea.

- Ahozko ekoizpeneko eta elkarrerginezko gaitasunak garatzea.

- Ikus-entzunezko material bat egiteko behar diren baliabideak hautatzea.

- Baliabide eta material digital horiek partekatzen jakitea.

Booktuberrek gero eta leku handiagoa hartu dute sare sozialetan, eta irakurzaletasuna sozializatzeko eta gazteen artean irakurketa sustatzeko fenomenotzat hartu dira (Tomasena, 2021). Gainera, azterlan batzuek ikusi dute nola You Tubek aldaketa ekarri duen irakurketa sustatzeko bitartekaritza tradizionaletan, hala nola eskolan edo liburutegietan. Egia da ikasle helduaren profiletik aldentzen den gazte fenomenoaz hitz egiten dela, eskaintzen zaien materialaren artean belaunaldien arteko distantzia egon arren, helduentzako prestakuntzako irakasleentzat erronka gisa ikus daiteke, hau da, zergatik ez? Gazteek bakarrik egin dezakete?

Booktuberren gaineko materiala erabiltzearen aldeko argudio bat da norberaren ingurunearen zatitzat jotzea. Adibidez, izan ziren nerabearekin edo hurbilen duen nerabearekin (seme-alabak, bilobak, ikasleak...) identifikatzen direnetik aurrera. Azken batean, gazte-materialaren eta bere ingurunearen eta esperientzia pertsonalaren arteko lotura sortzen saiatzea. Horregatik, jarraian azalduko dugun proiektua proposamen didaktiko bat baino zerbait gehiago da, hizkuntza-edukiak baino gehiago eman dezakeena, baita belaunaldien muga mugakideak probatu eta gainditzen saiatzeko esperientzia ere, gutxi ezagutzen den eremu baterantz jauzi egin eta gure gazteengana hurbildu eta mundu baten bidean egon ahal izateko, eta horrek sare sozialek eskaintzen dizkiguten ekimenetara eramaten gaitu.

\section{Taldea osatzeko fasea}

(sinkronoa - asinkronoa)

Taldeak osatzeko unean, kontuan hartu beharko litzateke taldea osatzen duten kideek elkar ezagutzen duten jada, edo, aitzitik, talde berria den, hau da, proiektu hau ikasturtearen hasieran hasten den. Bigarren kasu horretan, komeni da modu sinkronoan egitea, integrazio ona egon dadin laguntzeko eta "itsu-hitzorduak" saihesteko. Aitzitik, finkatutako talde bat proposatzen badugu, modalitate asinkronoa aukera dezakegu. Zenbait jarduera daude.

A. Bikoteka edo 3 laguneko taldetan: galdetu zure ikaskideei zer gustu literario dituzten. Pentsatu 3 galdera zure gustu eta lehentasun literarioekin lotuta.

B. Ikus-entzunezko ulermena: Ikusi bideoa (Caja Navarra Fundazioa, 202I) Zer liburu gomendatzen dituzu? Ezagutzen al dituzue egileak? Irakurri al duzue aipatutako libururen bat?

C. 4. irudian, e-Liburutegiaren zerrendako liburu batzuk agertzen dira, 2020an mailegatuenak, hain zuzen. Irakurri al duzue liburu horietakoren bat? Irakurri ez badituzue, zer gairi buruz hitz egin dezakezue? Zer arrasto ematen dizuete irudiek? Eta izenburuak? 

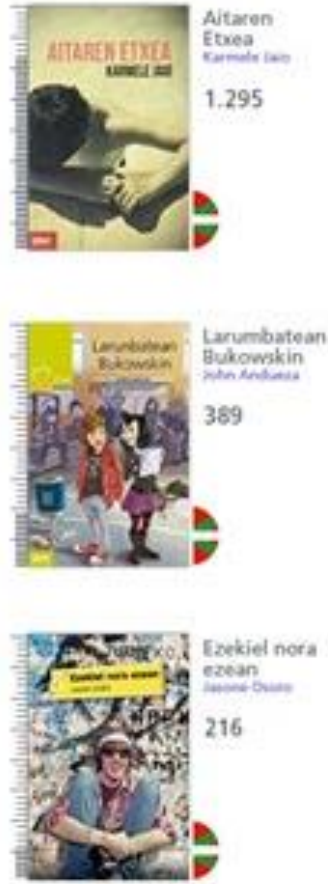
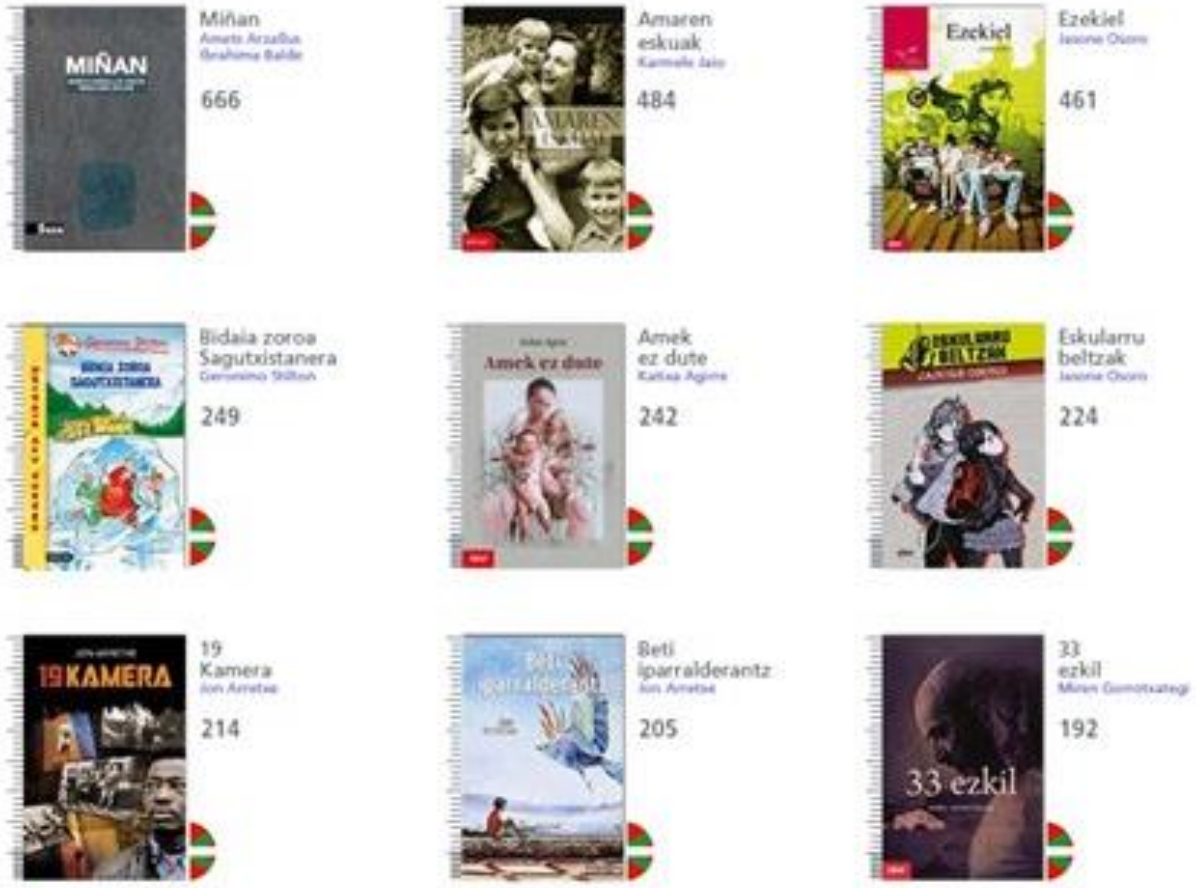

\section{Lana banatzeko fasea}

Lana jarduera-sekuentzia honetan banatuta dago (A-F).

A jarduera.

Hasteko bi aukera.

- Asinkronoa.

Taldeak aurreko fasean osatu ziren. Hurrengo jardueran, kide bakoitzak 120 eta 150 hitz artean laburbildu beharko duen liburu bati buruzko informazioa bilatuko du. Hori egin ondoren, informazio hori taldeko gainerakoekin partekatuko du lankidetza-panel bat baliatuta (adibidez, Wakelet edo Padlet).

- Sinkronoa.

Guztien artean liburu bat aukeratu behar dute batera irakurtzeko. Garrantzitsua da ikasle guztiekin negoziatzea zenbat denbora emango zaien liburua amaitzeko. Jarduera horrek negoziazioaren garapena eta taldearen erabakia behatzeko balio dezake. Horretarako, arreta jarri beharko litzateke gure ikasleek praktikan jartzen dituzten hizkuntzabaliabideetan, eta haien esku-hartzeetan agertzen diren akatsak, hutsuneak edo zalantzak jaso beharko lirateke. Gero, laguntza-plan bat jarriko litzateke abian, haien beharrei erantzuteko. Baita lorpenen atzeraelikadura positiboa ere.

Ikasgela digitalizatzeko oso baliabide erabilgarria da sarean aurkitzen ditugun aplikazioen bidez bozketa proposatzea; adibidez, Mentimer edo Pollwherever aplikazioen bidez. Erreferentziazko estekak sartzen direnean, aholkuak QR kode bihurtzen dira. 


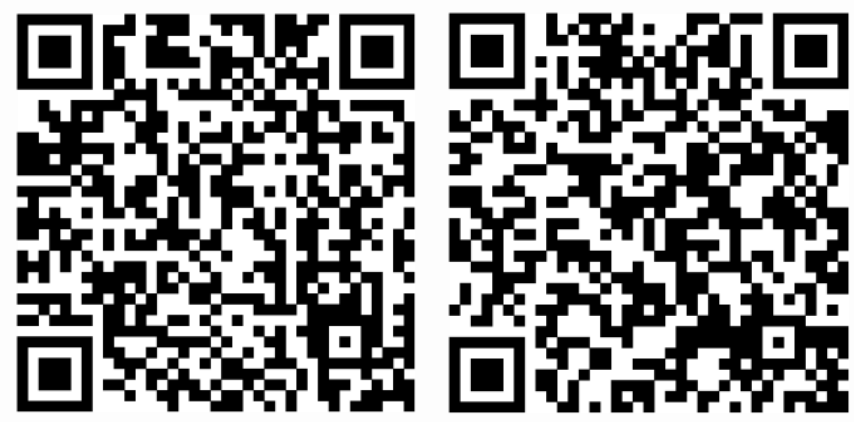

B jarduera

(sinkronoa edo asinkronoa)

Hasteko, bideo bat ikusten da bi aldiz: Booktuberboom booktube kanala (2020)

Egokitzat jotzen den modalitatea lortu nahi den helburu didaktikoaren araberakoa izango da. Adibidez, eztabaida gisa proposatzen bada, komeni da modu sinkronoan egitea, zuzenean praktikan jartzea ikusteko eta nola garatzen den ikusteko. Are gehiago, ahozko eta idatzizko interakzioaren arteko forma mistoa izan daiteke, berehalako mezularitzako kanal baten bidez. Aitzitik, modu asinkronoan egiteko, ikasgelako foro batean plantea daiteke, parte-hartzaileak beren iruzkinak idazten joan daitezen. Kasu horretan, garrantzitsua da epe bat jartzea kideen parte-hartzea errazteko.

Gainera, norabide bakarreko iruzkinak ez izateko estrategiak erabil daitezke, hala nola:

Erantzun galdera honi:

Zer egin behar da lehiaketa honetan parte hartzeko? Zer da booktuber bat?

Zure erantzunetan, erabili hitz hauetako bat: laburpena, aholkuak, apalategiak, bideoa.

Zuen hitzaldietan ezin duzue zuen ikaskideak erabili duen hitza errepikatu.

Komentatu zure ikaskideekin.

C jarduera: booktuber-ren definizioa

(asinkronoa)

Bideo hauek banatuko dira taldekide bakoitzeko. Talde bakoitzean ikasle berde bat, gorri bat eta urdin bat daude. Bideoa ikusten duten bitartean, ikasle guztiek bete behar dute "Booktuber-fitxa" (6. irudia).

- ikasle berdea: Azken garaipena. Booktuberboom egitasmoa (https://youtu.be/Q5eAdg95-hY)

- ikasle gorria: Naia Yeste - Estolda jolasak (Jon Arretxe) \#Booktuberboom IV. (https://youtu.be/-_jBT1zJi5k)

- ikasle urdina: Beñat Chaves Alfonso - Gose Jokoak (Suzanne Collins) \#Booktuberboom IV. (https://youtu.be/KZiUeSftv4Q) 


\section{BOOKTUBER-FITXA}

Zer hizkuntza-eredu erabili behar da? Begiratu zer esamolde erabiltzen dituen irakurketak baloratzeko eta gomendatzeko.

Zein da bere diskurtsoaren erritmo egokia?

- Motela

- Azkarra

- Ertaina

Nola aukeratu bideoaren agertokia? Non grabatu bideoa?

Bideoan protagonista bat baino gehiago egon daiteke?

Zein da irudiaren planoa? Zein distantzia dago hitz egiten duenaren lekuaren eta kameraren artean?

Zenbat irauten du?

Liburua erakusten du?

Modu sinkronoan edo asinkronoan:

Taldeka, partekatu informazioa eta azaldu, labur, zer den booktuber bat. Azaldu ezaugarriak eta helburuak. Beharrezkoa bada, bilatu informazio gehiago sarean.

Jarduera hau dokumentu partekatu batekin egin daiteke, elkarlaneko idazketa errazteko.

D jarduera: hiztegia

(sinkronoa edo asinkronoa)

Booktuber-ren bideoetan jarduera errepikakor batzuk aurkezten dira. Honelako jarduerekin ohitzeko, hurrengo hiztegi-ariketa egingo dugu.

Erlazionatu ezker zutabeko elementuak eskuin zutabekoekin: 


\begin{tabular}{|ll|l|}
\hline I. Houls & A. Laster irakurriko dituzun liburuak \\
\hline 2. Book Tag & $\begin{array}{l}\text { B. Videohauls-etan inspiratuta; pilulak dira, } \\
\text { non gazteek beren azken arropa-erosketak } \\
\text { erakusten dituzten, liburuen mundura erama- } \\
\text { nak. }\end{array}$ \\
\hline 3. Bookshelf Tour & $\begin{array}{l}\text { C. Gai berezietarako etiketa, erronkekin, bi- } \\
\text { txikeriekin, eztabaidekin... }\end{array}$ \\
\hline 4. Unboxing & $\begin{array}{l}\text { D. Aldi batean irakurritako irakurketen iruz- } \\
\text { kinak: astebetean, hilabetean, udan... }\end{array}$ \\
\hline 5. Wrap up & \begin{tabular}{l} 
E. Booktuber baten liburutegira bisita \\
\hline 6. Vlog
\end{tabular} & $\begin{array}{l}\text { F. Erositako edo oparitutako liburu-pakete } \\
\text { bat iristen da... "eta kameraren aurrean } \\
\text { ireki!" IMM ere (ingelesetik: My Mailbox) ere } \\
\text { erabiltzen da, nire postontzian, alegia. }\end{array}$ \\
\hline 7. TBR & G. Blog bat bideo formatuan \\
\hline
\end{tabular}

Soluzioa:

$1-\mathrm{B}, 2-\mathrm{C}, 3-\mathrm{E}, 4-\mathrm{F}, 5-\mathrm{D}, 6-\mathrm{G}, 7$ - A

\section{E jarduera: "a-b-d pertsonaien" booktag-a}

Booktuber-rek proposatzen duten erronketako bat hauxe da: booktag-ak, esate baterako, "A-B-D pertsonaiak". Taldeka, pertsonaien "A-B-D" bat egingo da, 7. irudian ezarritako urratsak eginez.

\section{7.irudia}

I. Pentsatu, banaka, irakurri dituzun liburuetako pertsonaien izenak, ordena alfabetikoari jarraituz.

2. Partekatu zure pertsonaien zerrenda hau zure ikaskideekin, haiei buruzko informazioren batekin batera: Zein liburutan agertzen dira? Zein dira haien rolak argudioan? Gustatu al zitzaizkizun?

3. Taldean, lotu pertsonaia interesgarrienak ordena alfabetikoan.

4. 10 minutu dituzue zerrenda komuna egiteko.

5. Bukatu ondoren, partekatu zerrenda ikasgelako txatean.

F jarduera: bideo bat grabatzea

A jardueran, talde bakoitzari liburu bat aukeratzeko eskatu zaio, irakurtzeko; beraz, bideoa booktuber gisa egiteko aukeratutako liburua berreskuratzen da.

Modu asinkronoan, ikasleek honako zeregin hauek bete beharko dituzte:

- Gidoi bat sortu.

- Lekua aukeratu.

- Rolak banatu: bideoan nor agertuko den, alderdi teknikoaz eta muntaiaz nor arduratuko den.

Irakaslea baliabide erabilgarriak eskaintzeaz arduratzen da: dokumentu partekatuak, bideoak egiteko aplikazioak, hizkuntza-euskarriko laguntza. 


\section{Taldeak desegiteko fasea}

Modu sinkronoan edo asinkronoan plantea daiteke.

- Jarduera sinkronoa: talde guztien lana bateratzea eta pareen artean ebaluatzea. Azkenean, botazio bat egin daiteke gehien gustatu zaizkien lanekin, eta sari bat eman.

- Jarduera asinkronoa: galdetegia betetzea. Hona hemen adibide bat, baliagarria izan daitekeena: Proyecto transmedia:LCdePapELE y PiérdetELEporMilán

\subsection{ZURE IKASTETXEAN EUSKARAZ IRAKURTZEA SUSTATZEKO KANPAINA BAT SORTZEA}

Jarraian aurkeztuko diren jardueren segidaren helburu orokorra honako hau da: zure ikastetxean irakurketa sustatzeko eta ikasgelako taldearen kohesioa sustatzeko kanpaina bat sortzea. 1.4 atalean azaldutakoari jarraikiz, garrantzitsua da H2ko eskolan taldeak osatzea ikaskuntza eraginkorragoa izateko.

Hona proeiktu honekin lortu nahi diren helburu nagusiak:

- Bigarren hizkuntzan irakurtzeko interesa piztea.

- Ikaslea irakurketa-espazio bat egiten inplikatzea.

- Ikasleak H2ko liburuen egungo izenburu batzuekin harremanetan jartzea.

- Testu baten edukia ezagutzea.

- Testu baten informazio nagusiak bereiztea.

- Testu bati buruz duten balorazioa eta iritzia azaltzen jakitea.

- Informazio espezifikoa aurkitzea, argudioak indartzeko.

- Informazioa hautatzeko estrategiak praktikan jartzea.

- Laburpen bat idazten jakitea.

- Benetako materiala erabiliz lexikoa zabaltzea.

- Ahozko ekoizpeneko eta elkarreragineko gaitasunak garatzea.

- Ikus-entzunezko material bat egiteko behar diren baliabideak hautatzea.

- Baliabide eta material digital horiek partekatzen jakitea.

- Ikasteko eskumenak garatzea.

- Norberaren ongizate fisiko eta emozionalean eta talde-ongizatean laguntzea.

- Enpatia adieraztea eta gatazkak kudeatzea.

- Ikastetxea proiektuan parte hartzera bultzatzea.

- Ikastetxea komunitatean sar dadin sustatzea.

Hurrengo proposamena Euskaltzaleen Topaguneak, Pil-pilean euskara elkartearekin, Soraluzeko Udaleko Hizkuntza Politikarako Batzordearekin eta udal liburutegiarekin lankidetzan, antolatutako Irakurri, Gozatu eta oparitu kanpainan inspiratu da (Soraluzeko Udala, 2020), H2ko eskolarako aldaketa batzuk eginez egokitu baitaiteke. Hasiera batean, irakasleak aldez aurretik prestatu behar du, eta arreta jarri behar die funtsezko alde batzuei, proiektua behar bezala gauza dadin. Hona hemen gida txiki bat.

\section{Irakasleek aldez aurretik prestatzea}

1. Proiektu hau gauzatzeko laguntza eska dakiekeen liburutegiak identifikatzea lurraldean (auzoetako liburutegiak edo udal-liburutegiak).

2. Ikasleei proposatzea proiektuan parte hartuko duen liburutegiko txartela egin dezatela.

3. Liburutegiko arduradunarekin hitz egitea, maileguak bideratzeko lankidetza proposatzeko. Zuen ikastetxean liburutegirik ez badago, bookcrossing egitea proposa daiteke; hau da, ikastetxeko ikasle guztiek euskarazko liburu bat eman dezatela eta helburu horretarako espazio komun batean gorde dadila. Adibidez, liburutegi bat jartzeko korridore bat. Horretarako, irakasleak inplikatu behar dira. Hala ere, ezinezkoa bada, zuen ikastaldearentzat bakarrik egin daiteke. Hala, espazio bat eskain liteke ikasgelan liburuak jartzeko. 
4. Ikasleek bete beharreko fitxak egitea. Fitxak bi zati ditu: bata, liburuari buruzko datuekin (izenburua, egilea, laburpen laburra eta balorazio bat); eta bestea, moztu daitekeena, ikaskidearentzako izenarekin eta mezuarekin, idatzi duen pertsonaren izena agertu gabe.

5. Proiektua ikastetxeari erakutsiko zaio, eta zozketarako liburuak erosten parte hartzera bultzatu, eta liburua sarituei bidaltzera ere bai. Sarituek liburua ikastetxean jasotzea izan liteke aukera bat.

\section{Lana banatzeko fasea}

Lana jarduera-sekuentzia honetan banatuta dago (J-F):

A jarduera

(sinkronoa)

- Bideo hau ikustea: https://youtu.be/10D0Nv6cLGk (Euskaltzaleen Topagunea, 2020)

- Bideoa ikusi ondoren, ikasleei galdera hauei erantzuteko eskatuko zaie:

- Zer iragartzen du? Zer ohar ematen dira? Idatzi koadernoan.

- Bikoteka, idatzitako informazioa partekatuko duzue eta zerrenda edo infografia egingo duzue jarraibideekin.

SOLUZIOA

\begin{tabular}{|l}
\hline ZER EGIN BEHAR DA? \\
- $\quad$ Hartu liburutegiko liburu bat, eraman etxera eta gozatu irakurketaz. \\
- $\quad$ Pentsatu zein laguni oparitu nahi diozun liburu hori. \\
- $\quad$ Itzultzean, bete fitxa zure datuekin eta zure lagunarentzako mezu \\
batekin. \\
- 500 liburu zozketatuko dira jasotako fitxa guztien artean, eta sari- \\
tuek etxean jasoko dute liburua, oparitzeko prest. \\
Eman sorpresa bat zure lagunari.
\end{tabular}

B jarduera: bookcrossing-a sortzea

Ikasleek euskarazko liburu bat aukeratu behar dute, etxean dituenetatik. Liburu bat erosteko ere eska dakieke. Garrantzitsuena da ikasle bakoitzak euskarazko liburu zehaztugabe bat eramatea denbora-tarte mugatu batean, ikasgelako edo ikastetxeko funts komun bat sortzeko.

C jarduera: liburu bat aukeratzea

Ikasle bakoitzak liburutegitik edo bookcrossing-etik (sinkronoa) irakurri ez duen liburu bat aukeratuko du.

Liburua eskola-orduetatik kanpo irakurtzen da, eta, ondoren, irakasleak emandako fitxa beteko du ikasleak. Irakurketa amaitu ondoren, ikaskide batek liburu hori gomendatzea gustatuko litzaiokeela pentsatu beharko du, eta mezu sekretu bat idatziko dio, hau da, ez da agertu behar mezua idatzi duenaren izena. Alde hori, beraz, asinkronoa izango da.

D jarduera: mezuak banatzea

(sinkronoa)

Ikasleek liburu bat irakurri eta fitxa eman ondoren, liburu horiek mezuen hartzaileei banatuko zaizkie. Irakasleak ziurtatu behar du guztiek jaso dutela mezu bat. Hartzaile bakoitzak mezuaren egilea nor izan den jakin beharko du.

E jarduera: zozketa

(sinkronoa) 
Parte-hartzaile guztien artean liburu-sorta bat zozketatuko da, eta irakasleak aukeratuko ditu sariak.

\section{Taldea desegiteko fasea}

Jarduera: irteera-txartela (asinkronoa)

Ikasle bakoitzari galdera hauei erantzuteko eskatuko zaio:

- Nola sentitu zara proiektu hau egin bitartean?

- Zalantzarik izan al duzu?

- Zer 3 hitz daramazu esperientzia horretatik?

Klase hibridoen kasuan, komeni da posta elektronikoa aprobetxatzea eta buletinaren ideiarekin konbinatzea; hau da, irakaslea arduratzen da ikasle-taldeari mezu elektroniko bat bidaltzeaz aurreko galderekin. Taldearen kohesioaren araberakoa izango da, korrespondentzia pribatu gisa (irakaslea-ikaslea) edo kolektibo eta ireki gisa (irakasleagelako taldea) proposatzen bada. Garrantzitsua da galdera horiek jaso ondoren atzeraelikadura ematea; banaka edo taldeka egin daiteke.

\subsection{JARDUERA INDEPENDENTE OSAGARRIAK}

Hurrengo jarduerak aurreko proiektuetatik aparte egin daitezke edo proiektu horietan sar daitezke.

\subsubsection{Liburuaren knolling bat sortzea}

Jarduera asinkronoa da, eta talde bakoitzak liburu baten knolling-erako irudi bat aurkeztuko du. Zer da knolling-a? Mexikoko Fujifilmaren arabera (2018), argazkigintzako joera bat da, konposizio bat muntatzean datzana - hartualdi zenital batetik hasita -, objektuak elkarren artean 90 gradutan kokatzeko moduan jarrita. Irudikatzea kostatzen bazaizu, pentsatu nola konpontzen dituzten stockeko irudiek bidaiarako edo tresnetarako, makillajerako edo osagaietarako beharrezkoak diren gauzak. Objektu horiek estetikoki eta oso estilizatuta egokitzea da, nolabaiteko ordena- eta zehaztasun-maila dutela. 8. irudian adibide bat dugu.

8. irudia. Iturria: Thomas Martinsen @faceline (Unplash) https://unsplash.com/photos/CrnALaUMSA4




Nola aplikatu liburu batean? Liburua erakuts daiteke eta, ondoren, bilbea edo pertsonaia jakin bat irudikatu dezaketen objektuak jarri konposizio horretan. Adibide bat, baliagarria izan daitekeena, La Salle Griñónen jasotakoa da (2021).

\subsubsection{Elkarrizketa liburuko pertsonaiekin}

Bi zati ditu.

1. Jarduera prestatzea (asinkronoa):

Elkarrizketa bat planteatzen zaie pertsonaia bati edo liburu bati baino gehiagori. 10 galdera inguruko inprimaki bat egiteko eskatzen zaie ikasleei. Galderak liburuaren edukiarekin lotuta egon daitezke, edo urrats bat gehiago eman daiteke, eta pertsonaia horiek gaurkotasuneko gaiei buruz duten iritzia ematea proposa dakieke, hau da, pertsonaiek gaur egungo gai bati, berri bati buruz zer iritzi izango luketen. Azken aukera hori neketsua edo konplexuagoa da, baina aukera emango luke pertsonaien interpretazioan hausnarketa sakonagoa egiteko eta pertsonaiak errealago bihurtzeko, ikaslearen egungo testuingurura eramanda.

\section{Elkarrizketaren aurkezpena (sinkronoa)}

Elkarrizketa zuzenean egin daiteke ikasgelan, ikasleek elkarrizketa antzeztu ahal izan dezaten. Beste aukera bat da ikasleek grabatzea eta gero gainerako ikasleekin elkarlaneko taula batean partekatzea.

\subsubsection{Buletinak}

Jarduera asinkronoa da. Buletinak ikasleak gidatzeko balio dezake, talde-lanari buruzko aholkularitza eskaintzeko. Horregatik, gomendagarria da talde bakoitzak posta-trukerako taldeak egitea. Galderak mota honetakoak izan daitezke: Zer moduz doa lana? Jarduera egiteari buruzko zalantzaren bat izan duzue? Zertan lagun diezazuket? Oso garrantzitsua da jardueren garapenaren jarraipena egitea, sor daitezkeen arazoak doitzen joateko edo sor daitezkeen gatazkei aurrea hartzeko.

Itzultzailea: IVAPeko Itzultzaile Zerbitzu Ofiziala 


\section{Bibliografia eta erreferentziak}

Arnold, J. eta Foncubierta J.M. (2019). La atención a los factores afectivos en la enseñanza de ELE. Edinumen.

Booktuberboom booktube kanala (2020, maiatzaren 28a). Booktuberboom Gipuzkoako Booktuber Lehiaketa. [Bideoa]. https://youtu.be/Dley2lsVc9M

De Agreda, E. (2021). Antzerki-teknikak ikaskuntza-eragile gisa: rol-jokoa eta antzezpena. e-Hizpide, 98. https://doi.org/10.54512/GYZV4354

Dörney, Z. eta Murphey, T. (2006). Talde-dinamika hizkuntz ikasgelan. HABE

Euskaltzaleen Topagunea (2020, urriaren 13a). Irakurri, Gozatu eta Oparitu 2020. Nola parte hartu? [Bideoa]. https://youtu.be/10D0Nv6cLGk

Eusko Jaurlaritza (2021). Liburutegiak 2020. Eusko Jaurlaritzako Liburutegi Zerbitzua. https://www.euskadi.eus/contenidos/informacion/publ icacion_profesional_biblio/eu_def/adjuntos/Liburutegia k2020.pdf

Fujifilm de México (2018, uztailaren 20a). ¿Sabes qué es el knolling? [Blog-sarrera].

https://www.instax.com.mx/blogs/blog-instax/sabesque-es-el-knolling

Herrera, F. (2017). Gamifikazioa eta bigarren hizkuntzak: ikasgela, ikasteko jolas-esparru gisa. Hizpide, 87, 5-20. http://www.irakasbil.eus/argitalpenak/gamifikazioaeta-bigarren-hizkuntzak

Fundacion Caja Navarra (2021, urtarrilaren 19a). \#CIVICANencasa. Biblioteca. Recomendaciones para Adultos euskera. [Bideoa] https://www.youtube.com/watch?v=dZGS6uULiGg
Herrera, F. eta Pujolà, J. T. (2020). Bigarren hizkuntzen didaktikaren berrikuntza mapatzea: eremu bateko nodoak eta ertzak. $e$-Hizpide, 96.

http://www.irakasbil.eus/argitalpenak/h2en didaktikar en berrikuntza mapatzea

La Salle Griñon (2021, apirilaren 23a). Knolling literario día del libro.[Blog-sarrera] https://lasallegrinon.es/knolling-literario-dia-del-libro

Recomendación del Consejo de 22 de mayo de 2018 relativa a las competencias clave para el aprendizaje permanente (Texto pertinente a efectos del EEE) (Diario Oficial de la Unión Europea, 2018/06/04, C189/1-13) https://eurlex.europa.eu/legalcontent/ES/TXT/?uri=uriserv\%3AOJ.C.2018.189.01.00 01.01.SPA

Soraluzeko Udala (2020, urriaren 20a). Euskarazko irakurzaletasuna bultzatzen. https://www.soraluze.eus/eu/albisteak/euskarazkoirakurzaletasuna-sustatzen?set language $=\mathrm{eu}$

Ruiz, V., López, F. J. eta Torres, L.. (2021). Ebaluazioa hizkuntzen eskoletan. Egiteke dagoen berrikuntza. $e$ Hizpide, 98. https://doi.org/10.54512/PMWP3182

Tomasena, J. M. (2021). ¿Quiénes son los bookTubers?: características de los video-blogueros literarios en lengua española. Ocnos. Revista De Estudios Sobre Lectura, 20(2), 43-55.

Trujillo, F. (2017). Aprendizaje basado en proyectos. Líneas de avance para una innovación centenaria. Textos. Didáctica de la Lengua y de la Literatura, 78, 42-48.

Universidad Nebrija (2020). Plan de Actuación para el curso 2020-2021 y adaptación de las actividades formativas a la evolución del COVID-19 https://www.nebrija.com/pdf/covid19-plan-actuacioncurso-2020-2021.pdf

\section{Gehiago jakiteko}

Gayá Martínez, M. A. (2017). Trabajar por ambientes en $2^{\circ}$ ciclo de Educación Infantil. [Gradu-amaierako lana]. Universidad Internacional de la Rioja, https://reunir.unir.net/bitstream/handle/123456789/5 659/GAYA\%20MARTINEZ\%2C\%20MERCEDES\%20AMA LIA.pdf? sequence $=1$ \&isAllowed $=y$

Olivé, C. [@xtianolive.maslectura] (d.g.). Argitalpenak. [Instagrameko profila]. Instagram. Hemendik berreskuratua (2021/12/01) https://www.instagram.com/xtianolive.maslectura/
Revista Tips de Educación. (d. g.). Cifras reveladoras de la educación virtual. Hemendik berreskuratua (2021/12/01) https://tipseducacion.com/archives/323

Pontificia Universidad Católica de Chile. (d. g.). ¿Cómo hacer una clase híbrida? Hemendik berreskuratua (2021/12/01) https://user-eku1m4o.cld.bz/ManualClases-hibridas-UC 